\title{
Hubungan kontrasepsi implant dengan siklus menstruasi pada wanita usia subur
}

\author{
Anis Eka Putri $\left.{ }^{*}\right)$ \\ ${ }^{\left.1^{*}\right)}$ STIKES Adila Bandarlampung
}

\section{ARTICLE INFO}

Keyword:

Kontrasepsi

Implant

Siklus Menstruasi

\section{*) corresponding author}

Mahasiswa STIKES Adila Bandarlampung

Jl. Soekarno - Hatta No.110, Rajabasa, Kec.

Rajabasa, Kota Bandar Lampung, Lampung 35144

Email:

margarethrinjani89@gmail.com

https://doiorg/10.47679/makein 01142000003

\begin{abstract}
A B S T R A C T
Salah satu permasalahan dari laju pertambahan penduduk yaitu kegagalan program Keluarga Berencana (KB) yang ditunjukkan dari adanya angka dropout atau putus pakai. Angka dropout di Indonesia pada tahun 2017 secara umum masih tinggi sebesar 27 persen dengan tingkat putus pakai tertinggi adalah pil 41 persen, kondom 31 persen, dan suntik 25 persen. Tujuan dari penelitian ini adalah mengetahuan hubungan Kontrasepsi Implant dengan Siklus Menstruasi pada Wanita Usia Subur di Rajabasa Jaya Bandar Lampung Tahun 2019. Jenis penelitian ini adalah analitik kuantitatifdengan menggunakan rancangan cross sectional. pengambilan sampel menggunakan tehnik probability sampling. Populasi dalam penelitian ini adalah seluruh Wanita Usia Subur (WUS) yang sudah menikah dan menggunakan alat kontrasepsi. Hasil analisis hubungan penggunaan kontrasepsi implant dengan siklus menstruasi pada Wanita Usia Subur diperoleh hasil bahwa dari 19 wanita usia suburyang menggunakan kontrasepsi implant terdapat 12 orang (63,2 persen) yangmengalami gangguan siklus menstruasi dan 7 orang (36,8 persen) yang tidak mengalami gangguan menstruasi, sedangkan dari 71wanita usia subur dengan kontrasepsi non implant terdapat 23 orang (32,4 persen) yang mengalami gangguan siklus menstruasi dan 48 orang (67,6 persen) yang tidak mengalami gangguan siklus menstruasi. Uji statistik chi square diperoleh nilai $p$ value: 0,029 (lebih dari 0,05) artinya ada hubungan penggunaan kontrasepsi implant dengan siklus menstruasi pada Wanita Usia Subur.
\end{abstract}

This open access article is under the CC-BY-SA license.

\section{PENDAHULUAN}

Program keluarga berencana memiliki makna yang sangat strategis, komprehensif dan fundamental dalam mewujudkan manusia Indonesia yangsehat dan sejahtera. UU Nomor 52 Tahun 2009 tentang perkembangan kependudukan dan pembangunan keluarga menyebutkan bahwa keluarga berencana adalah upaya untuk mengatur kelahiran anak, jarak, dan usia ideal melahirkan, mengatur kehamilan, melalui promosi, perlindungan, danbantuan sesuai hak reproduksi untuk mewujudkan keluarga yang berkualitas (Kemenkes,2013).

Salah satu permasalahan dari laju pertambahan penduduk yaitu kegagalan program Keluarga Berencana (KB) yang ditunjukkan dari adanya angka dropout atau putus pakai. Angka dropout di Indonesia pada tahun 2017 secara umum masih tinggi sebesar 27 persen dengan tingkat putus pakai tertinggi adalah pil 41 persen, kondom 31 persen, dan suntik 25 persen. Dari keseluruhan akseptor dan sekitar 23 persen menyatakan karena alasan kesehatan, efek samping dan masalah kesehatan lainnya (BKKBN, 2017).

Pengguna kontrasepsi implant dapat berkurang karena adanya beberapa masalah kesehatan yang dialami oleh sebagian akseptor yang ditimbulkan oleh efek samping dari kontrasepsi implant diantaranya adalah peningkatan berat badan, gangguan pola menstrasi, peningkatan tekanan darah, timbulnya jerawat perubahan perasaan (mood) atau kegelisahan (nervousness) dan peningkatan tekanan darah. Lebih lanjut dikatakan bahwa umumnya penambahan berat badan dan perubahan siklus haid pada wanita yang menggunakan kontrasepsi implant merupakan hal yang paling sering dikeluhkan akseptor kontrasepsi implant (Hartanto,2013).

Berdasarkan data di Rajabasa Jaya Bandar Lampung dari 52 akseptor terdapat akseptor yang putus pakai (drop out) sebanyak 15,8 persen ( 8 orang) dan 7,69 persen ( 4 orang) 
memutuskan untuk menganti jenis kontrasepsi. Angka ini lebih tinggi dibandingkan dengan data di Kemiling dimana hanya terdapat 12,5 persen angka drop out. Berkaitan dengan keluhan terhadap adanya gangguan pola menstruasi dari 52 akseptor terdapat 14 akseptor (26,92 persen) mengeluhkan adanya gangguan pada pola menstruasinya diantaranya jarak antar mestruasi yang menjadi lebih lamanya waktu menstruasi yang berubah. Angka ini lebih tinggi jika dibandingkan dengan di Way Halim dari 64 akseptor yang putus pakai (drop out) hanya sebanyak 9,38 persen (6orang). Berdasarkan latarbelakang dan fenomena diatas peneliti tertarik untuk melakukan penelitian tentang "Hubungan Kontrasepsi Implant Dengan Siklus Menstruasi Pada Wanita Usia Subur Di Rajabasa Jaya Bandar Lampung Tahun 2019".

\section{METODE}

Jenis penelitian ini adalah analitik kuantitatif. Penelitian ini menggunakan rancangan dengan pendekatan cross sectional yaitu suatu penelitian yang dilakukan sesaat, artinya objek penelitian diamati hanya satu kali dan tidak ada perlakuan terhadap responden. pengambilan sampel menggunakan tehnik probability sampling yaitu tehnik pengambilan sampel yang memberikan peluang yang sama bagi setiap anggota populasi untuk dipilih menjadi sampel (Sugiyono, 2010).

\section{HASIL DAN PEMBAHASAN}

Distribusi Frekuensi penggunaan kontrasepsi implant pada Wanita Usia Subur

Hasil penelitian menunjukkan bahwa dari 90 responden terdapat 19 wanita usia subur yang menggunakan kontrasepsi implant sebanyak 19 orang (21,11 persen), dan kontrasepsi non implant sebanyak 71 orang ( 78,89 persen).

\section{Distribusi Frekuensi gangguan siklus menstruasi pada Wanita Usia Subur}

Hasil penelitian menunjukkan bahwa dari 90 responden wanita usia subur terdapat 35 orang $(39,89)$ yang mengalami gangguan siklus menstruasi dan sebanyak 55 orang $(61,11$ persen) yang tidak mengalami gangguan siklus menstruasi.

\section{Hubungan penggunaan kontrasepsi implant dengan siklus menstruasi pada Wanita Usia Subur}

Hasil uji statistik chi square diperoleh nilai $p$ value: $0,029<0,05$ artinya ada hubungan penggunaan kontrasepsi implant dengan siklus menstruasi pada Wanita Usia Subur di Kelurahan Rajabasa Jaya Bandar Lampung Tahun 2019. Nilai

\section{DAFTAR PUSTAKA}

Arikunto. Suharsimi. (2010). Prosedur Penelitian. Jakarta: Rineka Cipta.

Astuti. (2015). Hubungan Lama Penggunaan Kontrasepsi Implant Dengan Siklus Menstruasi. Jurnal Kesehatan Kartika Vol. 10 No. 3. Desember 2015.

BKKBN. (2017). Laporan Akuntabilitas Kinerja Instansi Pemerintah BKKBN, Jakarta: BKKBN

BPS. (2012). Indikator Kesejahteraan Rakyat. Jakarta:

Badan Pusat Statistik. BPS. (2018). Laju Pertumbuhan Penduduk menurut Provinsi. Jakarta:BadanPusat Statistik.
OR: 3,578 yang berarti wanita usia subur yang menggunakan kontrasepsi implant .memiliki risiko sebesar 3,578 untuk mengalami gangguan siklus menstruasi dibandingkan dengan kontrasepsi nonimplant. Hasil penelitian ini menunjukkan bahwa penggunaan kontrasepsi implant masih dengan persentase yang tidak terlalu tinggi dimana hal ini didukung dengan data Peserta KB Aktif Provinsi Lampung sebanyak 136.406 PUS sedangkan untuk penggunaan kontrasepsi implant sebanyak 12.776 (9,3 persen) dan data di Kelurahan Rajabasa Jaya Bandar Lampungdari 52 akseptor. Adanya hubungan antara penggunaan kontrasepsi implant dengan siklus menstruasi tersebut menunjukkan kesesuaian dengan teori yang menyatakan bahwa efek samping implant antara lain adalah gangguan pola haid, seperti terjadinya spotting, perdarahan haid memanjang atau lebih sering berdarah (metrorragia), amenorea, mual-mual anoreksi, pening, sakit kepala, kadang-kadang terjadi perubahan pada libido dan beratbadan, timbulnya acne (Wiknjosastro,2014).

\section{KESIMPULAN DAN SARAN}

PenggunaankontrasepsiimplantpadaWanitaUsiaSuburdi Kelurahan Rajabasa Jaya Bandar Lampung Tahun 2019 sebanyak 19 orang(21,11 persen).

Wanita Usia Subur yang mengalami gangguan siklus menstruasi di Kelurahan Rajabasa Jaya Bandar Lampung Tahun 2019 sebanyak 35 orang(39,89).

Ada hubungan penggunaan kontrasepsi implant dengan siklus menstruasi pada Wanita Usia Subur di Kelurahan Rajabasa Jaya Bandar Lampung Tahun 2019, dengan nilai $p$ value $(0,029)$ dan OR: 3,578.

\section{Bagi Wanita UsiaSubur}

Berdasarkan hasil penelitian mengenai adanya hubungan antara penggunaan kontrasepsi implant dengan siklus menstruasi tersebut maka diharapkan para wanita usia subur tidak terlalu khawatir dan terburu-buru mengambil keputusan untuk berhenti menggunakan kontrasepsi implant, namun jika gangguan berlanjut dan bertambah parah maka dapat dipertimbangkan untuk mengganti dengan jenis kontrasepsi lainnya.

\section{Bagi Keluarahan Rajabasa Jaya Bandar Lampung}

Untuk lebih dapat mengintensifkan pemberian penyuluhan tentang manfaat dan efek samping dari tiap jenis kontrasepsi sehingga akseptor dapat menentukan jenis kontrasepsi yang akan digunakan berdasarkan informasi yang ada tentang manfaat dan efek samping tersebut, serta meningkatkan jumlah pengguna akseptor KB implant mengingat manfaat yang diberikan dari efektivitas kontrasepsi dengan jangka yang cukup panjang.

Handayani. (2010). Hubungan Lama Penggunaan KB Implant dengan Jumlah Keluhan Pada Akseptor di Puskesmas Junrejo Kota Batu. Jurnal Keperawatan Vol.1 No. 1 umm.ac.id. tahun 2010.

Hartanto. (2013). Keluarga Berencana Dan Kontrasepsi. Jakarta: Pustaka Sinar Harapan.

Hastono. (2010). Statistik Kesehatan. Jakarta: Rajawali Press.

Kemenkes. (2013). Situasi Keluarga Berencana di Indonesia. Jakarta:

Kemenkes. Kemenkes. (2018). Profil Kesehatan Indonesia Tahun 2017. Jakarta. 
Manuaba IBG. (2012). Ilmu Kebidanan. Penyakit Kandungan Dan KeluargaBerencana Untuk Pendidikan Bidan. Jakarta: Penerbit Buku Kedokteran EGC.

Notoatmodjo. Soekidjo. (2012). Metodologi Penelitian Kesehatan. Jakarta: RinekaCipta.

Octasari. 2014. Hubungan Jenis dan Lama Penggunaan Alat Kontrasepsi Hormonal Terhadap Gangguan Menstruasi pada Ibu PUS di Kelurahan Binjai Kecamatan Medan Denai Kota Medan. Jurnal Kesehatan. Universitas Sumatera Utara. 
